\title{
Multi-epitope Folate Receptor Alpha Peptide Vaccine
}

National Cancer Institute

\section{Source}

National Cancer Institute. Multi-epitope Folate Receptor Alpha Peptide Vaccine. NCI

Thesaurus. Code C101777.

A peptide vaccine containing five immunogenic peptide epitopes of the human folate receptor alpha (FR alpha or FOLR1), including FR30, FR56, FR76, FR113, and FR238, with potential immunomodulating and antineoplastic activity. Upon administration, the multiepitope FR alpha peptide vaccine may induce a cytotoxic T-lymphocyte $(C T L)$ response ag ainst FR alpha-overexpressing tumor cells. FR alpha is a high-affinity folate-binding protein and a member of the folate receptor family; this receptor is overexpressed in a majority of ovarian cancers and in about $50 \%$ of breast cancers. 